\title{
REPRESENTASI MATEMATIS SISWA SMA DITINJAU DARI GAYA KOGNITIF FIELD DEPENDENT DAN FIELD INDEPENDENT
}

\author{
Hesti Ayu Ningtiyas \\ Pendidikan Matematika, Fakultas Matematika dan Ilmu Pengetahuan Alam, Universitas Negeri Surabaya \\ Email : hestiningtiyas@mhs.unesa.ac.id
}

\author{
Abdul Haris Rosyidi \\ Pendidikan Matematika, Fakultas Matematika dan Ilmu Pengetahuan Alam, Universitas Negeri Surabaya \\ Email : abdulharis@unesa.ac.id
}

\begin{abstract}
Abstrak
Representasi matematis penting untuk dikuasai siswa, karena membantu siswa untuk mengungkapkan ideide yang dimiliki siswa dalam berbagai bentuk representasi. Salah satu hal yang mempengaruhi perbedaan representasi siswa dalam menyelesaikan masalah adalah gaya kognitif siswa. Penelitian deskriptif kualitatif ini bertujuan untuk mendeskripsikan representasi matematis siswa SMA ditinjau dari gaya kognitif field dependent dan field independent. Subjek dalam penelitian yaitu dua siswa SMA kelas XI berjenis kelamin laki-laki dan berkemampuan matematika tinggi, yaitu satu siswa dengan gaya kognitif field dependent dan satu siswa dengan gaya kognitif field independent. Metode pengumpulan data diperoleh melalui GEFT (Group Embedded Figures Test), TKM (Tes Kemampuan Matematika), tes representasi matematis, dan wawancara. Hasil penelitian menunjukkan subjek dengan gaya kognitif field dependent merepresentasikan ide untuk mengerjakan soal dengan representasi simbol dan verbal. Subjek dengan gaya kognitif field independent merepresentasikan ide untuk mengerjakan soal dengan representasi simbol, visual dan verbal. Representasi simbol dan visual dilihat dari jawaban subjek, untuk representasi verbal berdasarkan penjelasan subjek pada saat wawancara.
\end{abstract}

Kata kunci : representasi matematis, gaya kognitif field dependent dan field independent

\section{Abstract}

Mathematical representation was important for students to master, because it helped students to express ideas that students had in various forms of representation. One of the things that affect the differences in student representation in problems solving is the student's cognitive style. This qualitative descriptive study aims to describe the mathematical representation of senior high school students in terms of the field dependent and field independent cognitive styles. The subjects in the study were two senior high school students of class XI, who were male and had high mathematical abilities, namely one student with a field dependent cognitive style and one student with a field independent cognitive style. Data collection methods were obtained through the GEFT (Group Embedded Figures Test), TKM (Mathematics Ability Test), mathematical representation tests, and interviews. The results showed that subject with the field dependent cognitive style represented the idea of working on the problem with symbolic and verbal representations. Subject with the field independent cognitive style represented the idea of working on the problem with symbolic, visual, and verbal representations. Symbol and visual representations seen from the subject answer, for verbal representation based on the subject explanation during the interview.

Keywords : mathematical representation, field dependent and field independent cognitive style 


\section{PENDAHULUAN}

Salah satu kemampuan yang harus dimiliki siswa dalam belajar matematika adalah representasi seperti yang diungkapkan The National Council of Teacher of Mathematics (NCTM, 2000) dalam Principles and Standards for School Mathematics. NCTM (2000) mencantumkan representasi (representation) sebagai salah satu standar proses selain kemampuan pemecahan masalah (problem solving), kemampuan beragumentasi dan membuktikan (reasoning and proof), kemampuan berkomunikasi (communication), dan kemampuan koneksi (connection).

NCTM (2000) menyebutkan bahwa kemampuan komunikasi matematika meliputi kemampuan untuk menyajikan ide-ide matematika secara verbal, dalam tulisan, gambar, grafik dan bentuk visual lainnya. Lebih lanjut, NCTM (2000) menyebutkan kemampuan komunikasi matematika siswa meliputi, (1) kemampuan mengungkapkan ide-ide matematika secara tertulis maupun lisan, menunjukkan, dan menggambarkannya secara visual; (2) kemampuan memahami, menafsirkan, dan mengevaluasi ide-ide matematika yang disajikan dalam bentuk tertulis, lisan, atau visual; dan (3) kemampuan menggunakan kosa kata matematika, notasi, dan struktur untuk mewakili ide, menggambarkan hubungan, dan memodelkan situasi.

Representasi adalah ungkapan dari ide-ide yang dipikirkan siswa sebagai bentuk untuk mencari atau mengungkapkan pemecahan masalah. Representasi penting dimiliki siswa karena melalui representasi dapat membantu siswa dalam mengomunikasikan pemikiran atau gagasan yang dipikirkan siswa, sehingga dapat mempermudah memahami konsep dan menyelesaikan masalah.

Menurut Hutagaol (2013) representasi matematis merupakan ungkapan dari ide matematika yang ditampilkan sebagai upaya memahami konsep matematika atau mencari solusi dari suatu masalah. Secara operasional bahwa representasi yang sering digunakan dalam belajar matematika yaitu (1) sajian visual seperti tabel, gambar, grafik; (2) notasi matematika; (3) teks yang ditulis (Cai, dkk 1996). Untuk mengetahui bentuk representasi matematis siswa diberikan tes representasi yang harus diselesaikan oleh siswa. Representasi matematis yang digunakan sesuai dengan indikator yang dibuat oleh Yazid (2012).

Tabel 1. Indikator Representasi Matematis

\begin{tabular}{|l|l|}
\hline Representasi & \multicolumn{1}{|c|}{ Bentuk-bentuk Indikator } \\
\hline $\begin{array}{l}\text { Representasi } \\
\text { Visual }\end{array}$ & $\begin{array}{l}\text { Menyajikan informasi ke dalam } \\
\text { bentuk gambar, diagram, grafik, dan } \\
\text { tabel. }\end{array}$ \\
\hline
\end{tabular}

\begin{tabular}{|l|l|}
\hline $\begin{array}{l}\text { Representasi } \\
\text { Simbol }\end{array}$ & $\begin{array}{l}\text { Membuat persamaan, model } \\
\text { matematika atau menuliskan rumus } \\
\text { dengan notasi matematika }\end{array}$ \\
\hline $\begin{array}{l}\text { Representasi } \\
\text { Verbal }\end{array}$ & $\begin{array}{l}\text { Menuliskan langkah penyelesaian } \\
\text { dengan kata-kata }\end{array}$ \\
\hline
\end{tabular}

Goldin (2002) membagi representasi menjadi dua bagian yaitu representasi eksternal dan representasi eksternal. Goldin (2002) menjelaskan bahwa representasi eksternal dalam bentuk bahasa, simbol, gambar atau bentuk yang terlihat lainnya, sedangkan untuk berpikir tentang konsep matematika menggunakan representasi internal. Representasi internal tidak bisa diamati secara langsung karena suatu konsep abstrak atau ide yang ada di dalam otak. Ide yang ada di dalam otak bagian dari proses berpikir tiap individu.

Karakteristik yang dimiliki setiap siswa dalam berpikir dan memecahkan masalah matematika tentu berbeda-beda. Perbedaan-perbedaan antar pribadi yang menetap dalam cara menyusun dan mengolah informasi serta pengalaman-pengalaman yang dikuasai dikenal sebagai gaya kognitif (Slameto, 2010). Winkel (1996) mengemukakan pengertian gaya kognitif sebagai cara khas yang digunakan seseorang dalam mengamati dan beraktivitas mental di bidang kognitif, yang bersifat individual, dan kerap kali tidak disadari.

Menurut Slameto (2010) salah satu gaya kognitif yang telah dipelajari secara meluas adalah gaya kognitif field dependent dan gaya kognitif field independent. Seseorang dengan gaya kognitif field dependent cenderung menerima sesuatu secara global dan mengalami kesulitan dalam memisahkan diri dari keadaan sekitar (Slameto, 2010). Sehingga siswa dengan gaya kognitif field dependent menyelesaikan masalah sesuai apa yang telah diajarkan guru. Sedangkan seseorang dengan gaya kognitif field independent cenderung menyatakan suatu gambaran lepas dari latar belakang gambaran dan memandang keadaan secara analitis (Slameto, 2010). Oleh karena itu, siswa dengan gaya kognitif field independent menyelesaikan masalah sesuai apa yang dipikirkan dan dapat menganalisis masalah tanpa bergantung pada penjelasan guru.

Saat menyelesaikan masalah matematika, siswa perlu representasi baik gambar, grafik, diagram maupun bentuk lainnya, hal ini sependapat dengan Sabirin (2014) bahwa representasi berguna dalam menyelesaikan sebuah masalah. Gaya kognitif yang dimiliki siswa mempengaruhi bagaimana siswa berpikir untuk menggunakan bentuk representasi yang dipahami, sependapat dengan Tyas (2016) bahwa gaya kognitif mempengaruhi representasi yang digunakan siswa. Pentingnya representasi membuat guru seharusnya memperhatikan ragam representasi yang digunakan dalam 
memecahkan masalah matematika terutama pada siswa SMA.

\section{METODE}

Penelitian deskriptif kualitatif ini bertujuan untuk mendeskripsikan representasi matematis siswa SMA ditinjau dari gaya kognitif field dependent dan field independent. Penelitian ini menggunakan instrumen tes GEFT (Group Embedded Figure Test), TKM (Tes Kemampuan Matematika), tes representasi, dan pedoman wawancara.

Data yang diperoleh dalam penelitian ini adalah hasil tes GEFT (Group Embedded Figure Test), hasil tes representasi, dan hasil wawancara. Penelitian dilaksanakan di salah satu SMA negeri di Kertosono. Siswa akan diberikan tes GEFT (Group Embedded Figure Test) dan TKM (Tes Kemampuan Matematika) untuk mengelompokkan gaya kognitif dan level kemampuan matematika siswa. Hasil jawaban siswa akan dikelompokan berdasarkan skor yang diperoleh siswa setelah mengerjakan tes yang diberikan. Dengan menggunakan teknik pengambilan subjek purposive sampling, diperoleh subjek yang diinginkan yaitu dua siswa dengan kemampuan matematika tinggi, berjenis kelamin laki-laki dan memiliki gaya kognitif yang berbeda. Kemudian dilakukan wawancara terhadap subjek yang dipilih dengan tujuan untuk menggali informasi yang belum terungkap saat tes tertulis.

Analisis data dalam penelitian ini ada dua yaitu analisis data hasil tes representasi matematika dan analisis hasil wawancara. Analisis data tes representasi matematis berdasarkan indikator representasi matematis. Berikut merupakah masalah yang digunakan dalam penelitian ini.

"Wisnu ingin membuat kandang yang beralaskan tanah untuk kelinci peliharaannya. Kandang tersebut tanpa tutup dan alas, alas berbentuk persegi panjang. Ayah Wisnu memberikan bahan untuk membuat kandang berupa kawat jaring sepanjang 100 meter. Wisnu ingin alas kandang tersebut memiliki luas yang maksimum. Tentukan ukuran alas kandang kelinci yang harus dibuat Wisnu!"

\section{HASIL DAN PEMBAHASAN}

\section{Hasil}

Berdasarkan tes yang diberikan kepada 31 siswa SMA kelas 11, dipilih dua subjek dengan gaya kognitif berbeda, dengan kemampuan matematika tinggi dan berjenis kelamin laki laki.

Tabel 2. Subjek Penelitian

\begin{tabular}{|c|c|c|c|}
\hline Nama & $\begin{array}{c}\text { Skor } \\
\text { GEFT }\end{array}$ & Gaya Kognitif & $\begin{array}{c}\text { Skor } \\
\text { TKM }\end{array}$ \\
\hline AM & 9 & Field dependent & 87 \\
\hline MFR & 17 & Field independent & 90 \\
\hline
\end{tabular}

\section{Gaya Kognitif Field Dependent (FD)}

Subjek FD dapat memahami maksud soal dengan baik. Berikut petikan wawancara dengan subjek FD.

\section{Peneliti : Coba kamu jelaskan maksud dari soal tersebut?}

Subjek FD01: Wisnu ingin membuat kandang yang tanpa tutup dan beralaskan tanah jadi bagian bawah kandang juga tanpa alas. Wisnu diberi bahan untuk membuat kandang sepanjang 100 meter, berarti keliling dari kandangnya nanti harus 100 meter. Terus disuruh menentukan ukuran alas kandang tapi dengan luas yang maksimum.

Peneliti : Darimana tau kelilingnya 100 meter?

Subjek FD02 : Karena bahan yang tersedia 100 meter.

Peneliti : Kalau membuat kandang dengan keliling lebih dari 100 meter boleh?

Subjek FD03 : Tidak boleh, karena bahan yang tersedia hanya 100 meter, tapi kalau buat kandang dengan keliling kurang dari 100 meter boleh, tapi belum tentu luasnya maksimum.

Peneliti : Jadi keliling sama dengan bahan yang tersedia?

Subjek FD04 : Iya.

Berdasarkan petikan wawancara di atas, subjek FD dapat memahami soal dari tes representasi dan dapat menjelaskan soal dari tes representasi dengan mengetahui ukuran kawat jaring yang tersedia, ukuran alas kandang yang harus dibuat dengan luas maksimum dan bahan yang tersedia sama dengan keliling kandang (FD01).

Gambar di bawah ini menunjukkan bagaimana subjek FD dalam mengerjakan tes representasi matematis.

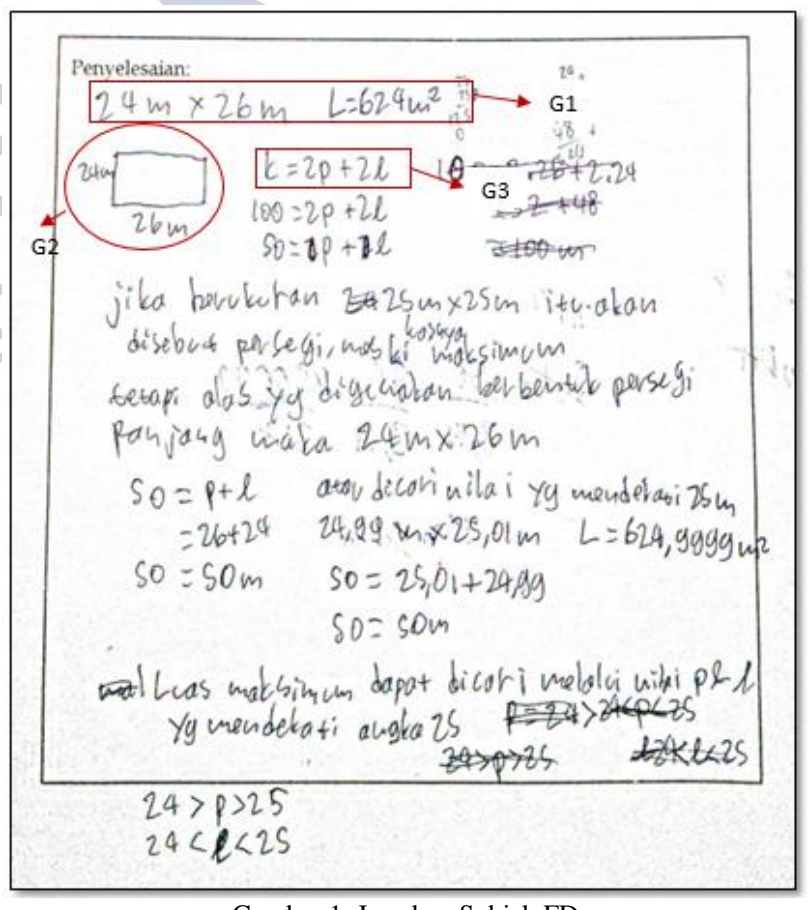

Gambar 1. Jawaban Subjek FD 
Dari hasil pengerjaan subjek FD, pada baris paling atas langsung menuliskan jawaban " $24 m \times 26 m$ dan $L=$ $624 \mathrm{~m}^{2}$ " (pada G1). Peneliti menanyakan maksud dari jawaban yang ditulis subjek FD pada saat wawancara. Berikut petikan wawancara dengan subjek FD.

Peneliti : Dari jawaban yang kamu tulis, maksud dari " $24 m \times 26 m$ dan $L=624 m^{2}$ " itu apa?

Subjek FD05: $24 m \times 26 m$ itu ukuran alas kandangnya, panjangnya 26 meter dan lebarnya 24 meter, lalu $L=624 \mathrm{~m}^{2}$ itu luas alas kandangnya.

Peneliti : Kenapa kamu memilih ukuran alas kandangnya $24 \mathrm{~m} \times 26 \mathrm{~m}$ ?

Subjek FD06: Karena yang mendekati 25 meter. Luasnya itu maksimum kalau ukuran alas kandangnya $25 \mathrm{~m} \times 25 \mathrm{~m}$, tapi karena bentuk alasnya persegi panjang jadi ukurannya harus yang mendekati 25 meter.

Peneliti : Awalnya kamu dapat ide mendekati 25 meter itu bagaimana?

Subjek FD07: Alas dari kandang berbentuk persegi panjang, nah kalau ukuran alas kandangnya $25 \mathrm{~m} \times 25 \mathrm{~m}$ itu $L=$ $625 \mathrm{~m}^{2}$. Jadi saya cari angka yang mendekati 25 meter supaya luasnya maksimum.

Peneliti : Pada lembar jawabanmu ada gambar (pada G2) maksudnya apa?

Subjek FD08: Maksudnya itu gambar alas kandang berbentuk persegi panjang dengan ukuran $24 \mathrm{~m} \times 26 \mathrm{~m}$.

Subjek FD menuliskan ide yang dimiliki mengenai ukuran alas kandang yang menurutnya memiliki luas maksimum yaitu " $24 m \times 26 m$ dan $L=624 \mathrm{~m}^{2}$ " (pada G1 dan FD05). Alasan subjek FD memilih ukuran tersebut karena mendekati 25 meter (FD06). Subjek FD memilih ukuran alas kandang dengan luas yang maksimum menurut subjek FD yaitu ukuran $25 m \times 25 m$ dan luas $L=625 \mathrm{~m}^{2}$, tetapi alas kandang berbentuk persegi (FD06). Namun karena subjek FD memahami jika alas kandang yang dibuat harus berbentuk persegi panjang, maka berdasarkan informasi yang di baca dari soal subjek FD mencari ukuran alas kandang yang dekat dengan ukuran alas kandang yang berbentuk persegi tersebut (FD07). Sehingga subjek FD menentukan jika ukuran alas kandang dengan luas maksimum yaitu $24 \mathrm{~m} \times 26 \mathrm{~m}$ (FD08). Dari jawaban dan penjelasan subjek FD, maka subjek FD menggunakan representasi simbol dan visual (pada G2) dalam mengerjakan soal.

Selanjutnya subjek FD menuliskan persamaan (pada G3) dalam lembar jawaban. Peneliti menanyakan maksud dari jawaban yang ditulis subjek FD, berikut petikan wawancaranya.
Peneliti : Coba jelaskan maksud dari huruf $K, p$, dan l?

Subjek FD09: $K$ itu keliling persegi panjang, $p$ itu panjang, dan litu lebar. Persamaan $(K=$ $2 p+2 l)$ itu rumusnya keliling persegi panjang, dengan keliling yang sama dengan bahan yang tersedia. Dari persamaan " $100=2 p+2 l$ " jadi " $50=$ $p+l$ " itu saya sederhanakan dibagi dengan 2.

Subjek FD menjelaskan maksud dari setiap permisalan yang digunakan dan dituliskan dalam bentuk persamaan. Subjek FD memisalkan K "keliling persegi panjang", p "panjang", dan 1 "lebar" (FD09). Dari penjelasan subjek FD, setelah membuat permisalan tersebut, subjek FD menuliskan rumus keliling persegi panjang yang diketahui kelilingnya (FD09). Kemudian subjek FD menyederhanakan persamaan yang didapat, untuk mempermudah subjek FD mengecek ukuran alas kandang yang ditentukan. Dari uraian tersebut maka subjek FD menggunakan representasi simbol.

Lanjutan jawaban subjek FD dan petikan wawancara berikut.

Peneliti : Jelaskan maksud dari kamu menulis "jika berukuran $25 \mathrm{~m} \times 25 \mathrm{~m}$ itu akan disebut persegi, meski luasnya maksimum, tetapi alas yang digunakan berbentuk persegi panjang maka $24 m \times 26 m$ "?

Subjek FD10 : Di soalnya itu suruh menentukan ukuran alas kandangnya, tapi luasnya harus maksimum dan alasnya berbentuk persegi panjang makanya ukuran yang saya pilih itu $24 \mathrm{~m} \times$ $26 \mathrm{~m}$.

Terus jawaban "atau dicari nilai yang mendekati 25 meter” maksudnya saya masukkan ukuran alas kandang ke rumus keliling persegi panjang yang sudah disederhanakan $(50=p+l)$, apakah ukuran tersebut kalau dimasukkan persamaan sama dengan 50 atau tidak. Saya coba kandang ukuran $26 \mathrm{~m} \times 24 \mathrm{~m}$ sama kandang ukuran 25,01 $\mathrm{m} \times 24,99 \mathrm{~m}$, kalau yang alas kandang ukuran $25,01 \mathrm{~m} \times$ $24,99 \mathrm{~m}$ itu luasnya $624,9999 \mathrm{~m}^{2}$ dan lebih luas dari alas kandang yang ukuran $26 \mathrm{~m} \times 24 \mathrm{~m}$.

Peneliti : Kenapa kamu tidak memilih yang ukuran 25,01 $m \times 24,99 m$ dari pada ukuran $26 m \times 24 m$ padahal itu kan lebih luas?

Subjek FD11 : Di kehidupan nyata nggak mungkin tukangnya mau ngukur dengan ukuran koma-koma. Kemudian saya tulis 
"24 $>p>25$ dan $24<l<25$ " maksudnya panjang sama lebarnya harus kurang dari 25 meter dan lebih dari 24 meter, tapi aku salah tanda untuk yang panjangnya.

Dari petikan wawancara di atas subjek FD menjelaskan maksud dari jawaban yang di tulis. Subjek FD memahami informasi dari soal untuk menentukan ukuran alas kandang kelinci yang luasnya harus maksimum dan alasnya berbentuk persegi panjang, maka ukuran alas kandang yang subjek FD tentukan yaitu ukuran $24 m \times 26 m$ (FD10). Subjek FD juga menjelaskan untuk mencari panjang dan lebar yang mendekati 25 meter karena menurut subjek FD luasnya akan maksimum kalau ukurannya mendekati 25 meter. Subjek FD juga mengecek kembali ukuran yang dia tentukan ke dalam rumus keliling persegi panjang apakah tidak melebihi 100 meter dari bahan yang ditersedia untuk membuat kandang (FD10). Serta subjek FD menyimpulkan jika panjang dan lebar dari alas kandang kelinci harus kurang dari 25 meter dan lebih dari 24 meter (FD11). Dari uraian tersebut, maka subjek FD menggunakan representasi verbal dan simbol dalam menyelesaikan soal.

Dibawah ini petikan wawancara sebjek FD dengan peneliti terkait representasi yang belum muncul yaitu representasi visual berupa tabel.

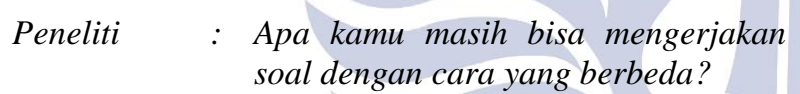

Subjek FD12 : Tidak kepikiran pakai cara lain.

Peneliti : Kalau persegi adalah persegi panjang yang sisinya sama panjang, gimana kamu mengerjakan soal itu?

Subjek FD13 : Nggak ada cara langsung jawab ukuran alas kandang adalah $25 \mathrm{~m} \times$ 25 m. Langsung nalar aja.

Peneliti : Kalau misal pakai tabel, kamu bisa mengerjakan?

Subjek FD14 : Bisa, tabel di buat untuk mendaftar kemungkinan ukuran panjang, lebar, dan luas alas kandang, tapi kalau pakai tabel kelamaan makanya saya tidak mengerjakan menggunakan tabel.

Subjek FD belum memiliki ide lain untuk mengerjakan soal. Setelah peneliti menjelaskan tentang definisi persegi, subjek FD mengerjakan soal tanpa cara (peneliti dan FD13). Alasan subjek FD langsung menjawab soal tersebut tanpa cara karena subjek FD menggunakan nalar atau logika dalam menjawab soal (FD13). Ketika peneliti meminta subjek FD untuk mengerjakan dengan tabel, subjek FD sebenarnya bisa mengerjakan menggunakan tabel, namun menurut subjek FD hal tersebut tidak efektif, karena harus mendaftar kemungkinan ukuran panjang, lebar, dan luas alas kandang (FD14).

Subjek FD juga belum memiliki ide untuk mengerjakan soal pada saat ditanya bisa mengerjakan selain menggunakan tabel, namun setelah peneliti mengaitkan dengan materi persamaan kuadrat yang pernah dipelajari oleh subjek FD. Subjek FD dapat mengerjakan soal tersebut dengan cara tersebut. Berikut ini petikan wawancara peneliti dengan subjek FD.

\section{Peneliti : Terus kalau pakai grafik, kamu bisa mengerjakan? \\ Subjek FD15 : Aku lupa mbak rumusnya. \\ Peneliti : Kalau ada fungsi yang menyatakan luas dari persegi panjang tersebut, bisa kamu nyatakan dalam bentuk persamaan? \\ Subjek FD16: Bisa, fungsinya $f(L)=50 l-l^{2}$. \\ Didapat dari mengalikan lebar dan panjang, tapi panjangnya dinyatakan dalam lebar biar ada satu variabel saja. Terus sampai situ bingung. \\ Peneliti : Pakai diskriminan lalu dicari titik puncaknya. \\ Subjek FD17: Bentar tak coba kerjakan dulu. Grafik berbentuk parabola terbuka ke bawah dengan titik puncak $(25,625)$. Berarti persegi termasuk persegi panjang mbak. Dan ukuran alas kandang yaitu $25 \mathrm{~m} \times 25 \mathrm{~m}$ dan luas $L=625 \mathrm{~m}^{2}$.}

Subjek FD bisa mengerjakan menggunakan representasi visual berupa grafik setelah peneliti mengingatkan subjek FD tentang materi persamaan kuadrat, meskipun pada awalnya subjek FD mengatakan bahwa lupa rumusnya (FD15). Setelah subjek FD mengingat materi persamaan kuadrat, subjek FD dapat menuliskan sebuah persamaan berupa fungsi yang menyatakan luas persegi panjang (FD16). Subjek FD juga bisa menjelaskan bahwa fungsi tersebut diperoleh dari mengalikan panjang dan lebarnya, namun dinyatakan dalam satu variabel (FD16). Setelah mendapat persamaan tersebut subjek FD bingung langkah selanjutnya untuk mengerjakan soal tersebut. Namun peneliti mengaitkan dengan materi diskriminan, sumbu simetri, dan titik puncak (FD17). Dari hasil wawancara subjek FD dapat menjelaskan bentuk grafik dari persamaan kuadrat tersebut, serta menjelaskan bahwa nilai fungsi maksimum saat di puncak dan dapat menentukan nilainya.

\section{Gaya Kognitif Field Independent (FI)}

Subjek FI dapat memahami maksud soal dengan baik. Berikut petikan wawancara dengan subjek FI.

$$
\begin{gathered}
\text { Peneliti } \quad \text { : Coba kamu jelaskan maksud dari soal } \\
\text { tersebut? }
\end{gathered}
$$


SubjekFI01: Dari soal diketahui bahan yang tersedia untuk membuat kandang 100 meter, maka otomatis keliling alasnya 100 meter. Nah dari 100 meter itu harus bisa dibuat kandang dengan luas alas maksimum itu dengan ukuran berapa. Terus kandang itu alasnya berbentuk persegi panjang.

Peneliti : Kalau semisal kamu membuat kandang dengan keliling alasnya lebih dari 100 meter boleh?

SubjekFIO2 : Tidak boleh, karena bahan yang tersedia cuma 100 meter tapi kalau mau buat kandang dengan keliling alas kurang dari 100 meter bisa, tapi belum tentu juga luasnya maksimum.

Berdasarkan petikan wawancara di atas, subjek FI memahami maksud soal dengan baik dan subjek FI juga dapat menjelaskan maksud soal tes representasi matematis (FI01). Subjek FI paham jika yang ditanyakan dari soal tersebut yaitu mencari ukuran alas kandang kelinci dengan luas maksimum (FI01). Subjek FI dapat menjelaskan jika informasi yang diketahui dari soal yaitu bahan yang tersedia untuk membuat kandang sama dengan keliling dari alas kandang yaitu 100 meter (FI02). Subjek FI paham jika ukuran alas kandang yang dicari luasnya harus maksimum, tetapi kelilingnya tidak boleh lebih dari 100 meter, namun kelilingnya boleh kurang dari 100 meter (FI02).

Gambar di bawah ini menunjukkan cara subjek FI dalam mengerjakan tes representasi matematis.

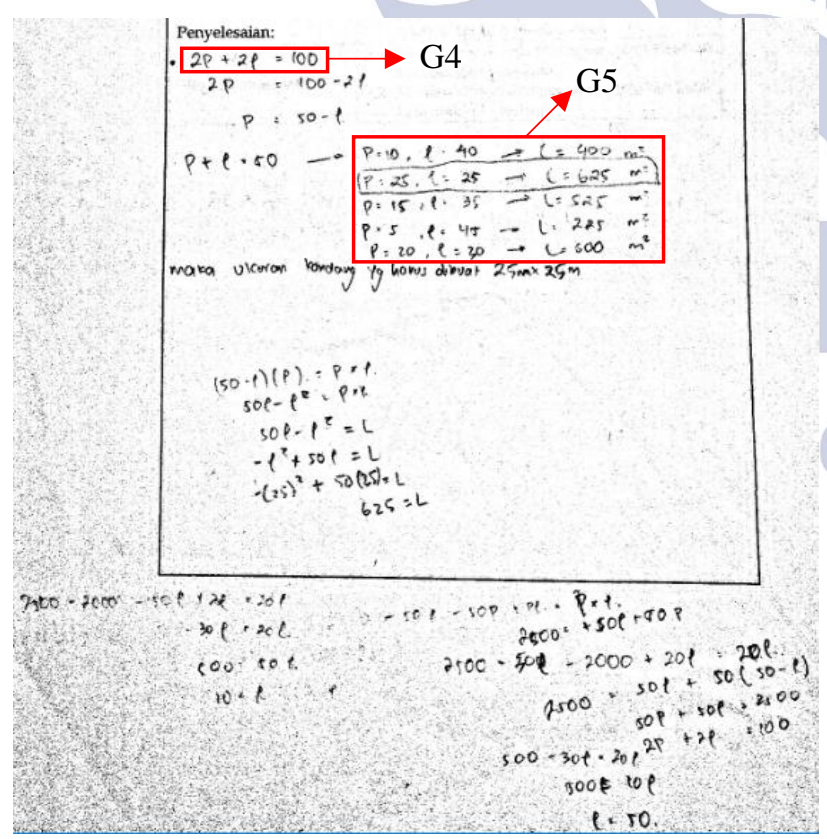

Gambar 2. Jawaban Subjek FI

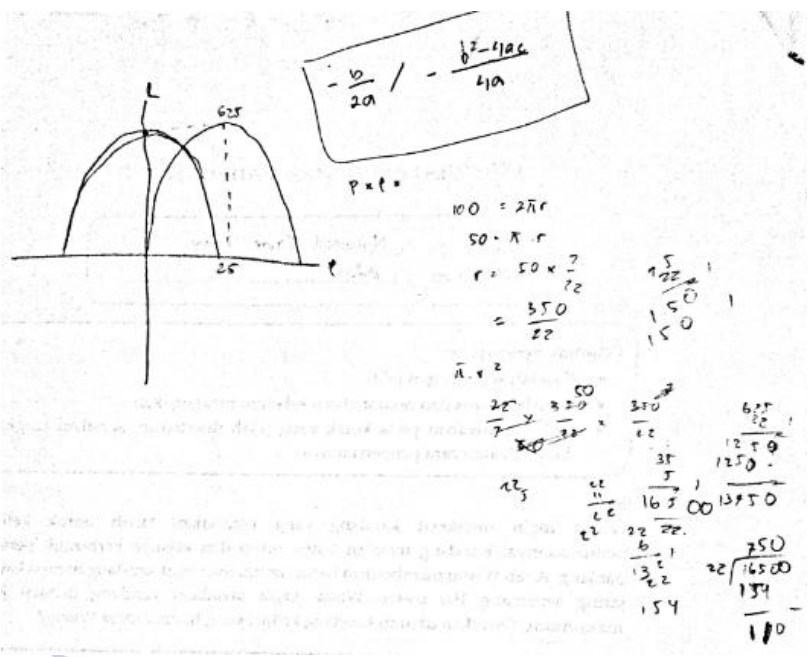

Gambar 3. Jawaban Subjek FI

Dari hasil pengerjaan di atas, subjek FI pada baris paling atas langsung menuliskan " $2 p+2 l=100 "$ (pada G4). Peneliti menanyakan maksud dari jawaban subjek FI tersebut pada saat wawancara. Berikut petikan wawancara dengan subjek FI.

Peneliti

Dari jawaban yang kamu tulis, coba jelaskan maksudnya $2 p+2 l=100$ apa?

Subjek FI03 : Misal p itu panjang, l itu lebar. Rumus keliling persegi panjang yaitu $2 p+2 l$ terus keliling alas kandang sama dengan bahan yang tersedia yaitu 100 meter.

Kemudian dari persamaan $2 p+2 l=$ 100 diubah menjadi $2 p=100-2 l$, karena saya mau mencari lebarnya dulu makanya dijadikan dalam p sama dengan.

Subjek FI menuliskan ide yang dimiliki yaitu rumus keliling persegi panjang yang diketahui kelilingnya sepanjang 100 meter (pada G4). Subjek FI dapat menjelaskan dari yang ditulis (pada G4) bahwa yang ditulis tersebut adalah rumus keliling persegi panjang, dengan memisalkan $\mathrm{p}$ adalah panjang dan 1 adalah lebar (FI03). Setelah mendapatkan persamaan $2 p+2 l=100$ subjek FI merubahnya menjadi $2 p=100-2 l$. Menurut subjek FI karena ingin mencari lebarnya terlebih dahulu sehingga dijadikan persamaan dalam 1 (FI03). Subjek FI juga paham jika mencari lebar atau panjang terlebih dahulu sama saja, bergantung kemauan yang mengerjakan soal (FI03). Dari jawaban dan penjelasan subjek FI, maka subjek FI menggunakam representasi simbol dalam mengerjakan soal.

Selanjutnya subjek FI menyederhanakan persamaan yang ditulis dalam lembar jawaban (pada G4). Peneliti menanyakan maksud dari jawaban yang di tulis subjek FI tersebut, berikut petikan wawancaranya. 
Peneliti $\quad$ Dari persamaan $2 p=100-2 l$
kenapa kamu jadikan $p=50-l$ ?

Subjek FIO4 : Itu saya sederhanakan terus saya jadikan $p+l=50$ lagi, soalnya saya kepikiran buat coba-coba ukuran persegi panjang yang cocok berapa, tapi dengan luas yang maksimum.

Terus dapat ukuran panjang sama lebarnya 25 meter saya kasih kotak.

Peneliti : Tapikan panjang sama lebarnya sama?

Subjek FIO5 : Karena seingat saya pas SMP dulu kalau ndak salah persegi itu termasuk dalam persegi panjang, makanya saya pilih yang ukuran $25 \mathrm{~m} \times 25 \mathrm{~m}$ dan $L=625 \mathrm{~m}^{2}$.

Peneliti : Kalau dari cara kamu yang coba-coba nyari ukuran panjang dan lebar yang luasnya maksimum itu bisa tidak dibuat tabel?

Subjek FIO6 : Bisa, malah lebih rapi tapi lama harus buat tabelnya terlebih dahulu.

Subjek FI menjelaskan maksud dari persamaan $2 p=$ $100-2 l$ yang diubah menjadi $p=50-l$ untuk disederhanakan, supaya langsung dapat ditentukan panjangnya jika di hitung (FI04). Namun setelah itu subjek FI menuliskan dalam bentuk $p+l=50$ karena subjek FI memiliki ide untuk mencari ukuran alas kandang dengan mencoba-coba ukuran yang luasnya maksimum (FI04). Ukuran yang dicoba subjek FI tertulis pada lembar jawabannya (pada G5), subjek FI memberi kotak untuk ukuran alas kandang dengan luas maksimum. Subjek FI tidak menuliskan kemungkinan ukuran yang memiliki luas maksimum menggunakan tabel karena menurutnya lama harus membuat tabelnya terlebih dahulu (FI06). Subjek FI memberi kotak pada ukuran $25 m \times 25 m$, karena menurutnya ukuran tersebut memiliki luas maksimum, serta subjek FI ingat definisi persegi termasuk persegi panjang (FI06). Dari uraian tersebut maka subjek FI menggunakan representasi simbol dan visual berupa tabel, namun tidak dibuat dalam bentuk tabel oleh subjek FI.

Lanjutan jawaban subjek FI dan petikan wawancara berikut.

Peneliti : Setelah kamu mendapat ukuran alas kandang tersebut kenapa kamu masih mengerjakan lagi tapi dengan cara yang berbeda?

Subjek FIO7 : Pengen nyoba aja kalau dicari pakai rumus luas itu hasilnya berapa ukuran alas kandangnya.

Peneliti : Coba jelaskan jawaban kamu dari cara yang katamu tadi cari pakai luas persegi panjang itu bagaimana?

Subjek FIO8 : Luas persegi panjang sama dengan panjang kali lebar, terus panjangnya tadi kan sudah saya ganti jadi $50-l$

kali lebar.

Diperoleh $50 l-l^{2}=p \times l$.

Dari situ saya bingung mau tak apakan. Tapi terus tak coba masukkan lebarnya 25 meter ternyata benar luasnya sama dengan 625.

Dari petikan wawancara di atas subjek FI menjelaskan maksud dari jawaban yang dia tulis. Subjek FI mengerjakan soal tersebut dengan cara yang berbeda dari cara sebelumnya, untuk memastikan apakah jawabannya juga sama dengan caranya yang sebelumnya (FI08). Subjek FI mencoba mengerjakan dengan menggunakan rumus luas persegi panjang (FI07). Dari uraian tersebut, maka subjek FI menggunakan representasi simbol dalam menyelesaikan soal dan representasi verbal dalam menjelaskan cara yang dipakai.

Di bawah ini petikan wawancara subjek FI dengan peneliti terkait representasi visual berupa grafik.

Peneliti

Kamu bisa mengerjakan pakai cara yang lain lagi?

Subjek FI09: Bisa, dari yang persamaan kuadrat itu bisa dibuat grafik, tapi aku gambar grafiknya cuma untuk menunjukkan titik puncaknya aja, jadi gambarnya tidak begitu bagus.

Peneliti : Coba kamu jelaskan?

Subjek FI10 : Dari persamaan $50 l-l^{2}=L$. Terus cara gambar grafiknya masukkan ke persamaan kuadrat tersebut lebarnya mulai dari 0 sampai 50, karena $p+l=50$ jadi nggak boleh lebih dari itu lebarnya.

Dari grafik tersebut dicari titik puncaknya.

Jadi ukuran alas kandang agar luasnya maksimum yaitu $25 \mathrm{~m} \times$ $25 m$ dengan $L=625 \mathrm{~m}^{2}$.

Subjek FI juga mengerjakan soal tersebut dengan menggunakan grafik, namun grafik yang dibuat hanya untuk menunjukkan letak titik puncaknya (FI09). Subjek FI menggambar grafik tersebut berdasar persamaan yang telah dia dapatkan dengan menggunakan rumus luas persegi panjang (FI10). Subjek FI menjelaskan jika grafik yang dibuat dengan memasukkan nilai dari lebarnya yaitu mulai dari 0 sampai 50, dia juga menjelaskan alasan kenapa hanya sampai 50 karena kelilingnya tidak boleh lebih dari 100 meter (FI10). Setelah grafiknya tergambar, kemudian dicari titik puncaknya dengan menghitung sumbu simetri dari titik puncaknya (FI10). Setelah menghitung sumbu simetrinya subjek FI menyimpulkan jika ukuran alas kandang dengan luas maksimum yaitu $25 m \times 25 m$ dengan $L=625 \mathrm{~m}^{2}$.

Dengan demikian subjek FI mengerjakan soal dengan berbagai cara dan pengetahuan yang dimiliki, dan pada 
saat wawancara subjek FI juga dapat menjelaskan jawaban yang dia tulis pada lembar jawabannya. Dalam mengerjakan soal tersebut subjek FI menggunakan berbagai cara dan berbagai representasi mulai dari representasi simbol, representasi visual berupa tabel dan grafik, serta representasi verbal dari cara subjek FI menjelaskan jawaban yang ditulis.

\section{Pembahasan}

Berdasarkan hasil analisis data, dalam menyelesaikan soal tes representasi matematis, subjek dengan gaya kognitif field dependent menggunakan satu cara dengan dua representasi, yaitu representasi simbol dan representasi verbal. Sesuai dengan Slameto (2010) bahwa individu dengan gaya kognitif field dependent akan mengalami kesulitan dalam menganalisis masalah dan menemukan kesulitan dalam mengubah strategi yang objeknya tidak biasa dilakukan.

Representasi simbol yang digunakan subjek FD untuk mengerjakan soal terkait dengan rumus keliling persegi panjang. Subjek FD sudah tepat dalam merepresentasikan penyelesaian dari soal dengan menggunakan rumus keliling persegi panjang, meskipun jawaban dari subjek FD masih kurang tepat. Hal tersebut terlihat dari penjelasan subjek FD pada saat wawancara terkait jawaban yang ditulis pada lembar jawaban. Subjek FD dapat mengerjakan soal dengan langkah-langkah yang tepat dan mengungkapkan ide yang dimiliki untuk mengerjakan soal secara global dan dipengaruhi oleh penjelasan guru. Sejalan dengan Witkin et.al (1977) bahwa individu yang memiliki gaya kognitif field dependent cenderung memandang masalah sebagai suatu keseluruhan, tidak memisahkan ke dalam bagianbagiannya (menerima sesuatu secara global) dan mengikuti struktur materi pembelajaran apa adanya. Meskipun jawaban subjek FD kurang tepat, subjek dapat menjelaskan dan menggunakan representasi simbol dengan tepat.

Representasi verbal yang digunakan subjek FD untuk mengerjakan soal terkait dengan pertanyaan dari soal untuk menentukan ukuran alas kandang kelinci dengan keliling 100 meter dan luas maksimum. Subjek FD masih kurang tepat dalam memahami maksud dari informasi yang ada pada soal. Subjek FD langsung mengungkapkan pemahamannya secara global, ini dapat dilihat dari penjelasan subjek FD jika informasi dari soal menyebutkan bahwa alas kandang kelinci berbentuk persegi panjang, maka subjek beranggapan bahwa kandang kelinci harus berbentuk persegi panjang. Padahal jika subjek FD lebih teliti maka bisa memahami kalau persegi termasuk persegi panjang yang kedua pasang sisinya sama panjang. Dan alas kandang yang berbentuk persegi tersebut memiliki luas yang maksimum. Sehingga subjek FD dapat merepresentasikan jawabannya secara global dan tepat dalam menggunakan representasi verbal.

Subjek FI dalam menyelesaikan soal tes representasi matematis menggunakan berbagai cara dan representasi. Subjek FI dapat menjelaskan setiap jawaban yang dia tulis, sehingga subjek FI menggunakan ketiga representasi yaitu representasi simbol, verbal, dan visual. Representasi simbol yang digunakan subjek FI untuk mengerjakan soal terkait dengan rumus keliling persegi panjang, rumus luas persegi panjang, dan persamaan kuadrat.

Subjek FI sudah tepat dalam merepresentasikan penyelesaian dari soal dengan menggunakan rumus keliling persegi panjang. Hal tersebut terlihat dari penjelasan subjek FI pada saat wawancara terkait jawaban yang ditulis pada lembar jawaban. Subjek FI dapat mengerjakan soal dengan menggunakan langkah-langkah yang tepat dan mengungkapkan ide yang dimiliki untuk mengerjakan soal secara analitis dan mengerjakan soal berdasarkan cara yang dia pahami sendiri. Sejalan dengan Mudjiono (2011) bahwa individu dengan gaya kognitif field independent cenderung lebih analitis dalam melihat suatu masalah. Sehingga subjek FI dapat menjelaskan dan menggunakan representasi simbol dengan tepat.

Subjek FI juga mengerjakan menggunakan cara lain untuk memastikan jawaban menggunakan cara sebelumnya sudah benar. Subjek FI sudah tepat dalam merepresentasikan penyelesaian dari soal dengan menggunakan luas persegi panjang dan persamaan kuadrat. Hal tersebut terlihat dari penjelasan subjek FI pada saat wawancara terkait jawaban yang ditulis pada lembar jawaban. Subjek FI dapat mengerjakan soal dengan menggunakan langkah-langkah yang tepat dan mengungkapkan ide yang dimiliki untuk mengerjakan soal secara analitis. Sesuai dengan Slameto (2010) bahwa individu dengan gaya kognitif field independent mampu menghadapi permasalahan tentang analisis. Sehingga subjek FI dapat menjelaskan dan menggunakan representasi simbol dengan tepat.

Representasi visual yang digunakan subjek FI untuk mengerjakan soal yaitu berupa tabel dan grafik. Meskipun subjek FI tidak membuat tabelnya, namun pada pengerjaannya, subjek FI memberi kotak untuk ukuran alas kandang yang memiliki luas maksimum. Sehingga hal tersebut sudah memenuhi indikator representasi, yaitu sudah menggunakan representasi visual berupa tabel. Subjek FI juga menggunakan representasi visual berupa grafik untuk mengerjakan soal tersebut. Subjek FI menggambar grafik untuk mengetahui titik puncak dari grafik tersebut. Subjek FI lebih teliti dan analitis dalam mengerjakan soal. Sesuai dengan Slameto (2010) bahwa individu dengan gaya kognitif field independent memandang keadaan yang perlu diselesaikan secara analitis. Sehingga subjek FI dapat merepresentasikan 
jawabannya secara analitis dan tepat dalam menggunakan representasi visual.

Pada saat wawancara, subjek FI dapat menjelaskan jawaban yang dia tulis dengan bahasa dan kalimat yang jelas dan bisa dipahami. Subjek FI sudah tepat dalam memahami maksud dari informasi yang ada pada soal. Sehingga subjek FI dapat merepresentasikan jawabannya secara analitis dan tepat dalam menggunakan representasi verbal. Subjek FI dalam mengerjakan soal berdasar yang dia pahami dan dalam menginterprestasikan representasinya secara analitis. Sejalan dengan Witkin et.al (1977) bahwa individu yang memiliki gaya kognitif field independent dalam merespon stimulus cenderung menggunakan persepsi yang dimilikinya sendiri sehingga lebih bersifat analitis. Dengan demikian, subjek FI memiliki representasi yang beragam dalam mengerjakan soal yang di berikan, dan menginterpretasikan representasi yang dimiliki secara analitis.

Tabel 3. Representasi Tes Tulis dan Hasil Wawancara

\begin{tabular}{|c|c|c|c|}
\hline $\begin{array}{c}\text { Repre } \\
\text { sentasi } \\
\end{array}$ & Tes Tulis & $\begin{array}{c}\text { Wawanca } \\
\text { ra }\end{array}$ & Kesimpulan \\
\hline \multirow[b]{2}{*}{ Visual } & - & - & \multirow[b]{2}{*}{$\begin{array}{l}\text { Subjek FI bisa } \\
\text { mengerjakan soal } \\
\text { dengan } \\
\text { representasi } \\
\text { visual, sedangkan } \\
\text { subjek FD tidak }\end{array}$} \\
\hline & $\begin{array}{l}\text { Subjek FI } \\
\text { mengguna } \\
\text { kan grafik } \\
\text { dan tabel }\end{array}$ & $\begin{array}{l}\text { Subjek FI } \\
\text { menjelask } \\
\text { an alasan } \\
\text { menggam } \\
\text { bar grafik } \\
\text { dan tabel }\end{array}$ & \\
\hline \multirow[b]{2}{*}{ Simbol } & $\begin{array}{l}\text { Subjek FD } \\
\text { mengguna } \\
\text { kan rumus } \\
\text { keliling } \\
\text { persegi } \\
\text { panjang }\end{array}$ & $\begin{array}{l}\text { Subjek FD } \\
\text { menjelask } \\
\text { an maksud } \\
\text { setiap } \\
\text { simbol } \\
\text { yang } \\
\text { digunakan }\end{array}$ & \multirow{2}{*}{$\begin{array}{l}\text { Subjek FI lebih } \\
\text { analitis dalam } \\
\text { mengerjakan soal } \\
\text { dengan } \\
\text { representasi } \\
\text { simbol } \\
\text { dibandingkan } \\
\text { dengan subjek } \\
\text { FD }\end{array}$} \\
\hline & $\begin{array}{l}\text { Subjek FI } \\
\text { mengguna } \\
\text { kan rumus } \\
\text { keliling } \\
\text { dan luas } \\
\text { persegi } \\
\text { panjang, } \\
\text { persamaan } \\
\text { kuadrat } \\
\text { dan } \\
\text { sumbu } \\
\text { simetri } \\
\end{array}$ & $\begin{array}{l}\text { Subjek FI } \\
\text { menjelask } \\
\text { an setiap } \\
\text { jawaban } \\
\text { yang di } \\
\text { tulis } \\
\text { dengan } \\
\text { rumus } \\
\text { yang } \\
\text { berbeda }\end{array}$ & \\
\hline \multirow[t]{2}{*}{ Verbal } & $\begin{array}{l}\text { Subjek FD } \\
\text { menulis } \\
\text { jawaban } \\
\text { dengan } \\
\text { kata-kata }\end{array}$ & $\begin{array}{l}\text { Subjek FD } \\
\text { menjelask } \\
\text { an maksud } \\
\text { kata-kata } \\
\text { yang di } \\
\text { tulis } \\
\end{array}$ & \multirow{2}{*}{$\begin{array}{l}\text { Meskipun subjek } \\
\text { FI tidak } \\
\text { menuliskan } \\
\text { jawaban dalam } \\
\text { representasi } \\
\text { verbal namun } \\
\text { dalam } \\
\text { menjelaskan } \\
\text { jawaban subjek }\end{array}$} \\
\hline & - & $\begin{array}{l}\text { Subjek FI } \\
\text { menjelask } \\
\text { an dengan } \\
\text { tepat dan }\end{array}$ & \\
\hline
\end{tabular}

\begin{tabular}{|l|l|l|}
\hline & analitis & FI sudah tepat \\
dari & dan jelas \\
jawaban & \\
yang di & \\
tulis & \\
\hline
\end{tabular}

Dari berbagai representasi yang digunakan subjek, terdapat satu representasi yang sama yaitu representasi simbol. Meskipun jawaban dari kedua subjek tidak sama. Representasi simbol yang digunakan oleh kedua subjek terkait dengan rumus keliling persegi panjang. Representasi simbol yang digunakan subjek FD hanya dalam satu cara tersebut, meskipun jawaban dari subjek FD kurang tepat. Sedangkan representasi simbol yang digunakan subjek FI dalam tiga cara, yaitu terkait dengan keliling persegi panjang, luas persegi panjang, dan sumbu simetri.

Pada representasi verbal subjek FD menuliskan jawabannya dalam kata-kata namun jawabannya kurang tepat, meskipun langkah-langkah pengerjaannya sudah benar, berbeda dengan subjek FI yang tidak menuliskan jawabannya menggunakan representasi verbal. Namun menggunakan representasi verbal dalam menjelaskan jawabannya dengan langkah-langkah pengerjaan yang sudah tepat.

Sedangkan pada representasi visual subjek FD pada lembar jawabannya tidak menggunakan representasi visual. Subjek FI menggunakan representasi visual berupa tabel dan grafik dalam mengerjakan soal tersebut.

Berdasarkan penelitian yang dilakukan Tyas (2016) menunjukkan bahwa siswa field dependent kurang tepat dalam menyelesaikan masalah matematika menggunakan representasi simbol dan siswa field independent menyelesaikan masalah matematika sudah tepat dalam menyelesaikan masalah matematika menggunakan representasi simbol, visual, dan verbal. Maka peneliti sependapat dengan Tyas (2016) karena subjek FD yang diamati tidak menyelesaikan masalah matematika menggunakan representasi visual dan jawaban kurang tepat, sedangkan subjek FI secara analitis dan tepat menggunakan representasi visual, simbol, dan verbal.

Berdasarkan penelitian yang dilakukan Mudjiono (2011) menunjukkan bahwa subjek field independent lebih analitis dalam menyelesaikan suatu masalah. Sesuai dengan penelitian yang dilakukan bahwa subjek FI lebih analitis daripada subjek FD. Meskipun dalam penelitian Mudjiono subjek penelitian berjenis kelamin berbeda.

Jadi, meskipun antara subjek FD dan subjek FI samasama berjenis kelamin laki-laki dan berkemampuan matematika tinggi. Subjek FD kurang analitis dan teliti dalam mengerjakan soal, serta lebih dipengaruhi dari penjelasan guru, sedangkan subjek FI lebih analitis dan teliti dalam mengerjakan soal, serta tidak bergantung pada penjelasan guru. Sesuai dengan Slameto (2010) bahwa 
gaya kognitif siswa mempengaruhi bagaimana siswa belajar dan bagaimana siswa menangkap penjelasan guru.

\section{PENUTUP}

\section{Simpulan}

Berdasarkan uraian di atas, representasi matematis siswa SMA ditinjau dari gaya kognitif field dependent dan field independent sebagai berikut, subjek dengan gaya kognitif field dependent mampu mengerjakan soal dengan menggunakan representasi simbol dan verbal. Dan subjek FD kurang analitis dalam mengerjakan soal. Subjek dengan gaya kognitif field independent mampu mengerjakan soal dengan menggunakan representasi simbol, visual, dan verbal. Dan subjek FI lebih analitis dalam mengerjakan soal. Untuk representasi verbal berdasar penjelasan pada saat wawancara. Representasi simbol, visual, dan verbal yang digunakan subjek dalam menyelesaikan soal sesuai dengan kemampuan dan pemahaman yang dimiliki masing-masing.

\section{Saran}

Penelitian lebih lanjut dibutuhkan untuk memperkuat atau memperluas hasil penelitian ini. Dalam pembelajaran matematika guru diharapkan lebih bervariasi memberikan latihan soal agar siswa dengan gaya kognitif field dependent dan field independent mampu menggunakan berbagai bentuk representasi.

\section{DAFTAR PUSTAKA}

Cai, Jinfa, Jakabcsin, Mary S., dan Lane, Suzanne. 1996. Assessing Students' Mathematical Communication. School Science and Mathematics. Volume 96(5).

Goldin, G. A. (2002). Representation in Mathematical Learning and Problem Solving. In L.D. English $(E d)$. International Research in Mathematical Education ICME, 197-218. New Jersey: Lawrence Erlbaum Associate.

Hutagaol, Kartini. 2013. Pembelajaran Kontekstual Untuk Meningkatkan Kemampuan Representasi Matematis Siswa Sekolah Menengah Pertama. Jurnal Ilmiah Program Studi Matematika STKIP Siliwangi Bandung. Vol. 02(1): hal.85-99.

Mudjiono. 2011. Profil Penalaran Siswa dalam Memecahkan Masalah Matematika Ditinjau dari Gaya Kognitif Field Dependent-Field Independent dan Perbedaan Gender. Tesis tidak dipublikasikan. PPs: Universitas Negeri Surabaya.

National Council of Teacher of Mathematics. 2000. Prinsiples and Standarts for School Mathematics. Reston, Virginia: NCTM.
Sabirin, Muhamad. 2014. Representasi Dalam Pembelajaran Matematika. Jurnal Pendidikan Matematika IAIN Antasari. Vol. 01(2): hal. 33-44.

Slameto. 2010. Belajar dan Faktor-Faktor Yang Mempengaruhi. Jakarta: PT. Rineka Cipta.

Tim Penulis. 2014. Buku Pedoman Penulisan dan Ujian Skripsi Unesa. Surabaya: Unesa.

Tyas, W. H. 2016. Representasi Matematis Siswa dalam Menyelesaikan Masalah Matematika Pada Materi Aritmatika Sosial Dan Perbandingan Ditinjau Dari Gaya Kognitif Siswa Kelas VII SMP Negeri 15 Surakarta Tahun Ajaran 2014/2015. Jurnal Elektronik Pembelajaran Matematika. Vol. 4(8): hal. 781-792.

Witkin, H. A. et.al. 1977. Field-Dependent and FieldIndependent Cognitive Styles and Their Educational Implications. Review of Education Research Winter 1977. Vol 47(1): pp. 1-64.

Winkel, S. 2009. Psikologi Pengajaran. Yogyakarta: Media Abadi.

Yazid, Ahmad. 2012. Pengembangan Perangkat Pembelajaran Matematika Model Kooperatif dengan Strategi TTW (Think Talk Write) Pada Materi Volume Bangun Ruang Sisi. Journal of Primary Educational. Vol. 01(1): hal. 31-37.

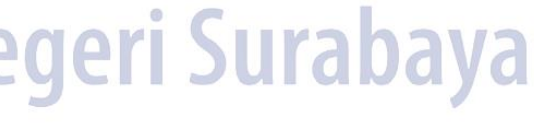

